Tunariu, A.D., Tribe, R., Frings, D. \& Albery, I.P. (in press, 2017). The iNEAR programme: an existential positive psychology intervention for resilience and emotional wellbeing. International Review of Psychiatry.

\title{
The iNEAR programme: an existential positive psychology intervention for resilience and emotional wellbeing
}

\section{ABSTRACT}

The aim of this study was to evaluate the effectiveness of a new psychological intervention, the iNEAR, which is a resilience and wellbeing programme consisting of a classroom based set of activities designed to facilitate the formation of positive identities through the acquisition of skills for growth and personal flourishing. 354 young people aged 11 and 12, matched for age and gender, were randomly allocated to the intervention ( 84 girls; 80 boys) and control conditions ( 93 girls; 96 boys). Following the intervention, boys, compared to girls, showed higher levels of wellbeing and environmental mastery and higher levels of tolerance to uncertainty. The intervention was effective in increasing appreciation of positive relationships with others, for girls and, although not statistically significant, it generated change in the desired direction for boys. In contrast to boys, girls' scores on openness to diversity also increased between baseline and post-intervention. Ways in which positive psychology interventions can resource individuals to better respond to adversity, coercion and personal uncertainty and so contribute to safeguarding against the adoption of extreme belief systems are also discussed.

Key words: resilience; existential positive psychology interventions; personal development.

\section{Dr Aneta D. Tunariu}

Head of Subject for Psychological Interventions, School of Psychology, University of East London a.tunariu@uel.ac.uk

\section{Professor Rachel Tribe}

Professor of Applied Psychology, School of Psychology, University of East London r.tribe@uel.ac.uk

\section{Dr Dan Frings}

Associate Professor, Division of Psychology, School of Applied Sciences, London South Bank University fringsd@1sbu.ac.uk

\section{Professor Ian P. Albery}

Professor of Psychology, Director of Research \& Enterprise, School of Applied Sciences, London South Bank University

alberyip@1sbu.ac.uk 


\section{INTRODUCTION}

The path to autonomy and authentic self-concept is wrought with challenges, ambivalence and vulnerability. Developing a firm sense-of-self entails risk and commitment (Macquarrie, 1974). As part of the process of delineating personal identity and individuality, an initially fragile ego is opening itself out to understanding, assimilating and committing to a mode of being that holds the promise of acceptance and value from others. This in turn, engenders self-acceptance and self-valuing.

Resilience. The developing self requires resilience. Resilience refers to the ability to bounce-back. It is the "process of, capacity for, [and] outcome of successful adaptation despite challenging or threatening circumstances" (Masten et al., 1990, p. 426). It also represents an enduring yet fluid "personality characteristic" related to an individual's repertoires of "adaptation" (Wagnild, 2003, p. 45). Positive psychology interventions provide a platform for working with (young) people to enable transformation through revised self-affirming narratives (Lomas \& Ivtzan, 2016) and individualised resources for personal growth (Parks \& Schueller, 2014). In the UK, for instance, interventions have been successfully tailored for education (e.g., MacConville \& Rae, 2012; Boniwell \& Tunariu, 2011) and youth restorative justice contexts (e.g., Boniwell \& Tunariu, 2010) and have increased participants' reported levels of happiness and motivation as well as their resilience and positive future perspectives. Greater resilience can improve problem solving skills, increase creativity and sense of self-efficacy (Springer et al., 2014). Together with exposure to positive emotions, resilience increases flexibility of thought (Corey \& Corey, 2014) and helps combat learnt helplessness and depression (Schroder \& Ollis, 2013). It also fosters greater engagement with learning, sense of belonging and connection with the school environment, and overall academic achievements (Nearchou et al., 2014).

Outline of iNEAR. The iNEAR programme is an existential positive psychology intervention designed to catalyse transformative change in the context of school education. It was piloted during 2016 at a school in South East England involving a sample of 350 young people aged 11 and 12. iNEAR's philosophy and intended outcomes were an ideal fit to the school's positive and socially responsible education ethos and culture. Its 7-lessons structure and style of delivery complemented the pedagogical approach local to the school and were delivered as an integrated as part of the PSHE (Personal, Social, Health and Economic) National Curriculum activities scheduled for the academic year.

The iNEAR programme facilitates the formation of positive identities, character strengths and resilience through the acquisition of skills for growth and flourishing (Tunariu, 2015). The term positive is used to denote an appreciative- vs. a deficit-centred model of psychological query. It conveys the discipline of positive psychology's commitment to recognising and promoting "conditions and processes that contribute to the flourishing or optimal functioning of people, groups, and institutions" (Gable \& Haidt, 2005 p. 104). Its overarching focus and the success of its applications to real life settings are "intrinsically and inescapably existential" (Wong, $2010 \mathrm{p} .1$ ). In short, (existential) positive psychology is about the human existence. A key question it asks is "What is a life worth living?" (Lindley et al., 2006). In its applications, it seeks to catalyse creative and hope-engendering momentum in relation to "the human drama of survival and flourishing in spite of suffering" (Wong, 2010 p.1).

iNEAR follows an appreciative inquiry approach and builds on awareness about self, others and self-with-others to derive new resources and meanings as well as engagement with the notions of social responsibility, ethics and existential choice. The focus is on $I$ as a social agent developing and (congruently) owning:

$\mathrm{N} \quad$ New knowledge about myself

E Emotional resources and emotional intelligence 
Development of $i N E A R$. The development and planning of the iNEAR programme took place against a global climate of socio-political discord, division and violent terror attacks. These led to a shared sense of personal and collective "existential threat" (as reflected in the PM Cameron's speech, July $20^{\text {th }} 2015$ ) and a search for certainty (Dechesne \& Kruglanski, 2004). Understanding psychological processes underpinning people's reactions to events that reject or infringe upon one's cultural way of life, norms and values (Van den Bos et al., 2005) has long been an interest across disciplines such as moral philosophy, sociology, applied psychology and allied professions. For instance, it has been aptly demonstrated how perceived fairness and the absence of (personal, community, existential) threat are crucial positive mediators for both the social organisation of human life and for the internal struggles of the human condition (Van den Bos, 2009). Events, such as the September 11th attack in the US, the attacks in London on July 7th and 21 st 2005 and 22nd March 2017, and the ongoing humanitarian crisis caused by multiple combat conflicts, make apparent the intertwined nature of personhood, social and cultural identity, and the assertion of power with potentiality for annihilating the Other. Research has shown that human tragedy brings to the front of our awareness our own mortality; and with it, a sense of insignificance, angst and a great deal of personal and existential uncertainty (Hogg et al., 2010). These conditions help generate a heighten state of self-preservation, stimulating (internalised or externalised) actions towards self-affirmation and a preoccupation with moral and social accountability (Borum, 2014) The upshot is an amplified human tendency to seek and align with those who harbour similar opinions, to defend against those whose opinions are dissimilar, and to overestimate the extent and coherence of consensus of views and values that are echoing one's own (Stillman \& Baumeister, 2009; Solomon et at., 2004).

The development and planning of the iNEAR programme also took place a time when British parents and educators were making sense of the Department for Education's "Prevent Duty" paper. The paper represents a call for action, advising schools and childcare providers about their crucial contribution towards preventing young people from being "drawn into terrorism" (DfE, July 2015). Resilience and character development, are identified as key social assets by the paper. For instance, it emphasises the need to build "children's resilience to radicalisation by providing a safe environment for debating controversial issues and helping them to understand how they can influence and participate in decision-making" (p.8). It could translate into initiatives aimed at raising awareness and equipping pupils with skills for recognising and managing risks to personal safety and wellbeing. The Prevent Duty paper also emphasises the crucial importance of promoting the development of "positive character traits" in the classroom such as "resilience, determination, self-esteem, and confidence" (p.8). Both these recommendations can be embedded in school curriculum activities designed to foster spiritual, moral and cultural development of pupils in ways that are appreciative of diversity, social justice and citizenship. Resilience in a school context, therefore, can be usefully conceived as a positive character attribute promoting optimal growth, self-actualisation and wellbeing and as a psychological shield to the risk of adopting extreme belief systems. In discussions with the Head Teacher of the participating school it became clear that these two aspects of resilience are complementary and, importantly, that their complementarity represents a realistic and valuable currency in today's realm of social ethics, personal development and education.

\section{Study aims and objectives}

iNEAR's conceptual and applied framework was conceived as a platform to generating insight learning, acceptance and skilled-nurturing of self in ways that enhances emotional regulation, resilience and wellbeing, which in turn, can enhance students' engagement with education and learning (Nearchou et al., 2014). When utilised to scaffold deliberate choice, agency and positive intra/inter personal action within the context of a wellstructured and nurturing school setting, resilience-oriented programmes are also known to provide useful psychological means to better overcome 
adversity (Gillian, 2000). iNEAR falls into this category as its framework can be used to enable the individual to better deal with various manifestations of coercion (Tunariu, 2017a). Philosophically conceived of as an existential dialogue, iNEAR can also be used to facilitate collaborative action within specific community defined and cultural contexts (Tunariu, 2017b). Following the above lines of reasoning, it is argued that mitigating against the risk of being persuaded by narratives of extreme value systems (e.g. as articulated in gang based cultures or football tribalism) can also be logically regarded as one of this programme's inherent outcomes. It may also be considered as a possible response to the Prevent Duty's call for due diligence as an early intervention framework that can house complementary initiatives by school and care providers for addressing the issue of extremist ideologies and philosophies in the lives of young people, sensitively and implicitly yet without minimising or avoiding it (Tunariu \& Tribe, 2015).

Researchers have identified normal psychological variables and factors (perception, reasoning, emotional states, psycho-social processes, responses) as playing a crucial role within the complex array of precursor components in progressing towards adopting extremist beliefs and radicalism of ideology (e.g., Hogg et al., 2010; Doosje et al., 2013; Borum, 2014; McGilloway, 2015). Against this background we wish to highlight the relevance of a systematic conceptual mapping between these normal variables and the normal variables that delineate the stage for personal development towards personal resilience, self-actualisation, inclusive social ethics and purpose-full future perspectives. The latter commonly emerge in clinical practice and are notable outcomes in post-traumatic work (e.g., Tedeschi, 1999). Further benefits are likely to be derived by deliberately harnessing their transformative potential through (existential) positive psychology interventions to inform multidisciplinary efforts in tackling issues pertaining to the risk of youth adopting extreme belief systems.

The aim of this paper is to evaluate the efficacy of the iNEAR psychological intervention and present key findings emerging from its $1^{\text {st }}$ wave of implementation. In doing so, we showcase a theoretically driven way of working with normal variables that facilitate positive identities and personal growth and argue that these can implicitly also strengthen the individual's resilience to being drawn into adopting extremist beliefs and values. The intervention is hypothesised to generate positive changes across four core domains: self-concept and self-relatedness; emotional regulation and relating to others; choice and options; responding with resilience (see Table 1). As the intended changes across each of these domains inherently exercise the 'muscle' of resilience (I am, I have, I share, I choose - Tunariu, 2015), it is theorised that the intervention will implicitly also enhance participants' resilience capacity.

\section{METHOD}

\section{Programme's structure}

The iNEAR programme constitutes a set of 7 self-contained one hour lessons that can be usefully housed by a larger positive-education curriculum. Each lesson is centred on a specific theme and intended outcome, realised through one or multiple activities. Each activity is intended to generate existential-type-moments-of-insight in the classroom. Across the lessons, participants follow the journey of the iNEAR character's quest for knowledge, dilemmas and their resolution (e.g., being right or doing the right thing). Some activities involve storytelling and interactive smallgroup feedback (e.g., 'What are my character strengths?', 'What qualities I would like more of?' and 'What do others see as my character strengths?'). Some are psycho-educational and focus on flexibility of thinking (e.g., blind-spots and the role of creativity), emotional intelligence and regulation of emotions. Other activities involve thought-experiments to stimulate experience-informed learning and rehearse updated habitsof-reasoning pertaining to gratitude, fairness, wellbeing, character virtue and existential choice. 


\section{Design}

This evaluation study compared control and treatment groups, matched in terms of age and gender. All the participants received the treatment following a random allocation into phase one (group A control and group B experimental conditions) or phase two (group A experimental and group B control conditions) of programme implementation. There were three points of data collection for each phase: base line (prior to Lesson 1), post-intervention (after Lesson 7) and at 3 months follow up (treatment group only). Table 1 shows the 7-lessons mapped onto the four core domains of change, each with respective intended outcomes and associated measures of evaluation.

\section{Participants}

A total of 354 school children took part in the first wave of pilot. The intervention condition involved 87 age 11 and 78 age 12 participants. The control condition involved 80 participates aged 11 and 109 aged 12. In the intervention condition, 84 participants were male and 80 female. In the control condition 96 were male and 93 female. Gender of participants was not shown to be associated with allocation to condition $\left(x^{2}(354)<0.01\right.$, $\mathrm{p}=.936)$.

\section{Procedure}

Ethical approval for evaluating the piloting of this intervention was obtained from the participating school and from the research ethics committees of two London-based universities. This included informed consent from the parents / guardians and the children. Two teachers (one male, one female) were identified by the school to deliver the iNEAR programme. Both were experienced teachers, responsible for delivering PSHE syllabus for the year 7 (age 11) and year 8 (age 12) cohorts of students. Programme and research related training was provided to these teachers. Data collection activities were completed by students within the normal class settings.

\section{RESULTS}

Analytical strategy. Each positive psychology domain was operationalised into a variable derived from psychometric outcomes (see Table 1). We conducted an analysis of covariance (ANCOVA) on each outcome variable, with Treatment (Treatment vs. Control) as a between-participants factor and Time (Baseline vs. Post intervention) as a within-participants factor. As we were also interested in whether the intervention was equally efficacious for males and females, we included gender as a second between-factor independent variable. The effects of age and academic performance (combined Maths and English average grades over six months prior to the intervention) we covaried and controlled for

Main effects. Table 2 provides the statistics for the main effects, covariate effects and interaction effects. A narrative summary and, where appropriate, simple effects tests are reported. Tests were undertaken using means adjusted for covariates reported in Tables 3 and 4.

Well-being. Subjective wellbeing increased over time in the experimental condition $\left(F(1,224)=12.54, p<.001, \eta_{\mathrm{p}}{ }^{2}=.05\right)$ and also in the control condition $\left(F(1,224)=2.18, p=.14, \eta_{\mathrm{p}}{ }^{2}=.01\right)$. This finding is strengthened by the analysis showing that the conditions did not differ at either time point $(p<.208)$. The main effect of gender was significant $(p=.056)$, reflecting higher levels of wellbeing amongst males $(M=50.47, \mathrm{SE}=.79)$ relative to females $(M=48.29, \mathrm{SE}=.81)$. Academic achievement was a significant covariate, and age approached significance as a covariate. There was no main effect of Time or of Treatment (ps >.47). Neither age nor academic achievement interacted with Time. 
Intolerance to Uncertainty. Neither age nor academic achievement acted as significant covariates. Age interacted with Time with marginal significance. There was a significant interaction between Time and academic achievement. There was no main effect of Time or Treatment. There was a marginally significant $(p=0.088)$ main effect of gender, reflecting higher levels of intolerance amongst females $(M=25.56, \mathrm{SE}=.74)$ than amongst males $(M=27.36, \mathrm{SE}=.74)$. Simple effects analysis revealed a difference in males and females post-intervention, with males $(M=$ $25.88, \mathrm{SE}=.82)$ experiencing greater tolerance to uncertainty than females $(\mathrm{M}=27.87, \mathrm{SE}=.81)(F(1,221)=5.32, p=.02)$. At baseline, score differences in intervention and control conditions were not statistically significant $\left(F(1,221)=.098, p=.75, \eta_{\mathrm{p}}{ }^{2}<.01\right)$. At the post-treatment point, they differed, with participants in the intervention condition on average demonstrating increased tolerance to uncertainty $(F(1,221)=.386, p .051$, $\left.\eta_{\mathrm{p}}^{2}=.02\right)$.

Environmental Mastery. Age was a significant covariate. Academic achievement was not, and no significant interactions involving the covariates were found. There was a main effect of gender, reflecting higher levels of emotional mastery amongst males $(\mathrm{M}=37.38$, $\mathrm{SE}=.50)$ than amongst females $(\mathrm{M}=35.76, \mathrm{SE}=.49)$. Simple effect analysis revealed an increase in sense of mastery between baseline and post-intervention in the intervention condition $\left(F(1,207)=4.36, p=.038, \eta_{\mathrm{p}}{ }^{2}=.02\right)$ but not in the control condition $\left(F(1,207)=0.02, p=.894, \eta_{\mathrm{p}}{ }^{2}<.01\right)$. The control and intervention groups did not differ at baseline $\left(F(1,207)=2.26, p=.13, \eta_{\mathrm{p}}{ }^{2}<.01\right)$ or post-intervention $\left(F(1,207)=0.01, p=.906, \eta_{\mathrm{p}}{ }^{2}=<001\right)$.

Positive Relationships with Others. Age was a significant covariate, academic achievement was not. The covariate did not interact with other factors. There was a marginal effect of Time, reflecting a general increase in ProW0 in post intervention $(M=39.57, \mathrm{SE}=.56)$ relative to baseline $(M=40.43, \mathrm{SE}=.58)$. Simple effects analysis revealed that ProW0 increased between baseline and post-intervention time-points $(F(1,208)=$ $\left.4.89, p=.028, \eta_{\mathrm{p}}{ }^{2}=.02\right)$. ProW0 did not change over time in the control conditions $\left(F(1,208)=.004, p=.949, \eta_{\mathrm{p}}{ }^{2}<.01\right)$. Intervention and control conditions did not differ at baseline $\left(F(1,208)=.47, p=.494, \eta_{\mathrm{p}}^{2}<.01\right)$. This was qualified by a significant three-way interaction between the independent variables (Table 3 ). Breaking this interaction down by gender, simple effects revealed that, amongst males, there was no statistically significant increase in ProW0 between baseline and post-intervention phase, in the experimental $\left(F(1,208)=.67, p=.41, \eta_{\mathrm{p}}{ }^{2}<.01\right)$ or control $\left(F(1,208)=3.10, p=.088, \eta_{\mathrm{p}}^{2}=.02\right)$ conditions. Amongst females, there was an increase in ProW0 between baseline and post intervention in the intervention condition $\left(F(1,208)=5.76, p=.017, \eta_{\mathrm{p}}{ }^{2}=.03\right)$ but not in the control condition $\left(F(1,208)=3.00, p=.085, \eta_{\mathrm{p}}{ }^{2}=.01\right)$.

Openness to Diversity and Challenge. Age and academic achievement were significant covariates. No interactive effects with covariates were observed. There were no significant main effects or two way interactions. The three-way interaction was significant (see Table 3). Amongst males, there was no increase in openness to diversity and challenge between baseline and post-intervention phase, in the experimental $(F(1,216)$ $\left.=0.73, p=.395, \eta_{\mathrm{p}}{ }^{2}<.01\right)$ or control $\left(F(1,216)=1.39, p=.24, \eta_{p}{ }^{2}<.001\right)$ conditions. Amongst females, there was an increase in openness to diversity and challenge between baseline and post intervention in the intervention condition $\left(F(1,216)=5.90, p=.016, \eta_{\mathrm{p}}{ }^{2}=.02\right)$ but not in the control condition $\left(F(1,216)=0.66, p=.797, \eta_{\mathrm{p}}^{2}<.01\right)$.

\section{DISCUSSION}

Statistical analyses presented above show significant changes between control and treatment groups across the four domains, in the intended direction. Following the intervention subjective wellbeing scores have increased as has a sense of control over one's immediate environment, openness to diversity and an appreciation of good relationships with others. The capacity to tolerate uncertainty and ambiguity also increased in 
the treatment condition. Overall, participation in the iNEAR was shown to be associated with reported increases in well-being, self-efficacy, positive relationships with others, openness to diversity and, importantly, to provide participants with psychological resources to better deal with and tolerate uncertainty. Although a follow up is planned, this has not been completed as yet. The intention is to re-measure the effects of the intervention at three, six and twelve months to determine if the effect remains and ideally, to consider a comparison with another intervention that has long-term outcome scores.

Identity formation is accelerated during the teenage years and remains an ongoing process in a (young) person's life as they search for a selfauthored identity and synthesis of socially indebted personal systems of value. Through the process of maturation, the emergent sense of self is often vulnerable to strong reactions, confusions, resistance to perceived rigid authority and dis-alignment from the familiar as an overcompensation for the need to stand out as unique. At the same time, there is the preoccupation to secure belonging to a group when attributed with kudos, social influence and currency is fit to render them a meaningful identity by association, through membership (Ball \& Nario-Redmond, 2014). Social groups, their norms and 'how to best conduct my life' knowledge foster avenues for dealing with periods of uncertainty. Group membership makes available resources to sustain self-esteem and confront existential concerns (with awareness or otherwise) such as delineating who self can be, life meaning and purpose (Greenberg et al., 1997).

Resilience is a capacity that can be expanded. It can be developed through interactions between an individual' internal assets, guided responses to environmental variables, and repertoires of protective factors (Luthar et al., 2000). iNEAR was designed to tap on such interactions. Its overreaching theory of chance is transformation through participation. As illustrated above, change follows a collective direction towards growth and optimal functioning. At the same time, change is necessarily subjective as at a given time, different themes resonate differently with each individual. As the first empirical test of method, the methodological strengths of this pilot study rest with its longitudinal, randomised design and the opportunities for further research that it opens up. The study's conditions came from the same school which raises issues of limited generalisability and possible sample contamination effects. However, it also means groups are comparable and served as possible moderators. Based on this $1^{\text {st }}$ wave of data, it was not possible to model maturational as well as intervention effects; a larger sample (from the $2^{\text {nd }}$ wave of data) would be needed to detect sustainability at 3-month follow-up.

A theoretical argument also proposed here is that by focusing on positive self-relating, identity formation and the acquisition of skills for growth and flourishing, we can also expand young people's resilience to narratives or pressures that promote extremist views and so lower the risk of them adopting extremist, non-liberal, discriminatory ideologies. Table 5 provides an example of the proposed conceptual mapping. For instance, components of uncertainty relating to self-doubt, to instability about world-views, to events that threaten in some way familiar social order or one's place within it, or to managing existential uncertainty (productively or side-stepping it), in distinct or combined ways - have been shown to have important explanatory power as precipitant conditions towards the risk of adopting extreme belief systems. For example, when in state or period of life characterised by existential uncertainty an individual is more likely to be susceptible to radical narratives or to the influence of extremist groups (Hogg et al., 2010). Similarly, uncertainty arising when 'truths' are questioned or thrown into ambiguity prompts re-evaluation, subsequent adjustment or an amplified alignment to existing worldviews. Potentially, the individual may elect to elevate their exiting "worldview defense" (Stillman \& Baumesister, 2009) which may translate in the individual searching for clear-cut, not-in-between views, norms and expectations. Inclusion into extreme groups may, therefore, become an attractive option as their philosophy tends to offer straightforward answers to complex questions and a structure of rules for conduct that reduces ambiguity and personal uncertainty (Hogg et al., 2010). Importantly, the developing-self thrives within the context of inter-personal relationships that are underpinned by a theory of mind able to 'witness' the other in a 
manner which, when 'seen', the (skilfully witnessed) individual can 'recognise' themselves and find the 'courage' to experiment towards becoming a congruent (new) self (Winnicott, 1958). Since the overall endeavour of resiliency and self-concept maturation is reliant on narratives and practices dominant to a hosting culture (Ungar \& Liebenberg, 2011), our education and systems of care are inescapably situated at the crucial intersection between personal growth and social responsibility.

From the vantage point of early intervention, approaching the risk of adopting extremist world-views indirectly, emerges as a valuable modality. It can be achieved through psycho-social programmes that focus on individual capacity for growth, resilience and well-being. These are best informed by a conceptual mapping between normal precursor components related to adopting extreme belief systems and normal variables that set the stage towards self-actualisation, positive relationships and inclusive social ethics. The approach can also be integrated to complement culturally sensitive clinical practice (Tribe \& Tunariu, in press). Its positive-enquiry ethos can help ease the task of engaging community stakeholders and beneficiaries to collaboratively engender meaningful and relevant change without (re)problematising or further alienating certain groups of people or communities (Tunariu et al., 2017).

\section{References}

Ball, T.C. \& Nario -Redmond, M. R. (2014). Positive social identity interventions. Finding a conduit or well-being in stigmatized group memberships. In A. C. Parks \& S. M. Schueller (Eds.). The Wiley Blackwell Handbook of Positive Psychological Interventions, Chichester: Wiley Blackwell. (Chapter 18, pp. 327 - 343).

Boniwell, I. \& Tunariu, A.D. (2011) (Eds.). Newham Resilience Curriculum Initiative. The SPARK programme: resilience and wellbeing in schools. Research Report and Trainer's Guide. Commissioned by Newham Council. London, UK.

Boniwell, I. \& Tunariu, A.D. (2010). Face Up: Emotional Resilience programme for young people. A Trainer's Guide and materials. Commissioned by London Metropolitan Police in association with The Young Foundation. London, UK.

Borum, R. (2014). Psychological Vulnerabilities and Propensities for Involvement in Violent Extremism. Behavioral Sciences and the Law, Vol. 32: $286-305$

Borum, R. (2011). Radicalization into Violent Extremism II: A Review of Conceptual Models and Empirical Research. Journal of Strategic Security Vol. 4 (4): $37-62$

Cameron, D. (July, 20th 2015). Extremism: PM speech. https://www.gov.uk/government/speeches/extremism-pm-speech Accessed July, $30^{\text {th }}$ 2015.

Carleton, R. N., Norton, M. A., \& Asmundson, G. J. G. (2007). Fearing the unknown: A short version of the intolerance of uncertainty scale. Journal of Anxiety Disorders, Vol. 21: 105-117. 
Corey, G. \& Corey, S. M. (2014). I never knew I had a choice. Explorations in personal growth. Cengage Learning: International Edition.

Dechesne, M. \& Kruglanski, A. W. (2004). Terror's epistemic consequences. Existential threats and the quest for certainty and closure. In J. Greenberg, S. L. Koole \& T. Pyszczynski (Eds). Handbook of Experimental Existential Psychology. New York: The Guilford Press. (Chapter 16, pp. $247-262)$.

Department for Education (July, 2015). The Prevent duty. Departmental advice for schools and childcare providers. https://www.gov.uk/government/publications/protecting-children-from-radicalisation-the-prevent-duty

Doosje, B., Loseman, A. \& Van den Bos, K. (2013). Determinants of Radicalization of Islamic Youth in the Netherlands: Personal Uncertainty, Perceived Injustice, and Perceived Group Threat. Journal of Social Issues, Vol. 69(3): 586 - 604.

Gable, S. L., \& Haidt, J. (2005). What (and why) is positive psychology? Review of General Psychology, Vol. 9: 103-110.

Gillian, R. (2000). Adversity, resilience and young people: the protective value of positive school and spare time experiences, Children \& Society, Vol. 14: $37-47$.

Greenberg, J., Solomon, S., \& Pyszczynski, T. (1997). Terror management theory of self-esteem and cultural worldviews: Empirical assessments and conceptual refinements. In M. P. Zanna (Ed.). Advances in experimental social psychology (Vol. 29, pp. 61-139). New York: Academic Press.

Hogg, M. A., Meehan, C., \& Farquharson, J. (2010). The solace of radicalism: Self-uncertainty and group identification in the face of threat. Journal of Experimental Social Psychology, Vol. 46: 1061-1066.

Lindley, P. A., Joseph, S., Harrington, S. \& Wood, A. M. (2006). Positive psychology: Past, present, and (possible) future, The Journal of Positive Psychology, Vol.1 (1): 3-16.

Lomas, T. \& Ivtzan, I. (2016). Second Wave Positive Psychology: Exploring the Positive-Negative Dialectics of Wellbeing, Journal of Happiness Studies 17(4):1753-1768

Luthar, S. S., Cicchetti, D., \& Becker, B. (2000). The construct of resilience: A critical evaluation and guidelines for future work, Child Development, Vol. 71: $543-562$

MacConville, R. \& Rae, T. (2012). Building happiness, resilience and motivation in adolescence. A positive psychology curriculum for wellbeing. London: Jessica Kingsley Publishers.

Macquarrie, J. (1974). Existentialism. An introduction, guide and assessment. Pelican Books.

Masten, A. S., Best, K. M. \& Garmezy, N. (1990). Resilience and development: Contributions from the study of children who overcome adversity. Development and Psychopathology, Vol.2: 425 - 444. 
Masten, A. S., Best, K. M. \& Garmezy, N. (1990). Resilience and development: Contributions from the study of children who overcome adversity. Development and Psychopathology, Vol.2: 425 - 444.

McGilloway, A., Ghosh, P. \& Bhui, K. (2015). A systematic review of pathways to and processes associated with radicalization and extremism amongst Muslims in Western societies International Review of Psychiatry, Vol. 27(1): 39-50.

Nearchou, F. A., Stogiannidou, A., Kiosseoglou, G. (2014). Adaptation and psychometric evaluation of a resilience measure in Greek elementary school students. Psychology in the Schools, Vol. 5(1): 58 - 71.

Parks, A.C. \& Schueller, S. (2014). Preface. In A.C. Parks \& S. Schueller (Eds.) The Wiley-Blackwell Handbook of Positive Psychological Interventions. Chichester: Wiley Blackwell (pp. XV - XIX).

Pascarella, E. T., Edison, M., Nora, A., Hagedorn, L. S., \& Terenzini, P. T. (1996). Influences on students' openness to diversity and challenge in the first year of college. Journal of Higher Education, Vol. 67: 174-195.

Ryff, C. (1989). Happiness is everything, or is it? Explorations on the meaning of psychological wellbeing. Journal of Personality and Social Psychology, Vol. 57: $1069-1081$.

Schroder, K. E.E. \& Ollis, C. L. (2013). The Coping Competence Questionnaire: A measure of resilience to helplessness and depression, Motivation and Emotion, Vol. 37(2):286-302.

Solomon, S. Greenberg, J. Pyszczynski, T. (2004). The cultural animal: twenty years of Terror Management theory and research. In J. Greenberg, S. L. Koole \& T. Pyszczynski (Eds). Handbook of Experimental Existential Psychology. New York: The Guilford Press. (Chapter 2, pp. 13 - 34)

Springer, C., Misurell, J., Kranzler, A., Liotta, L. \& Gillham, J. (2014). Resilience interventions for youth. In A. C. Parks \& S. M. Schueller (Eds.). The Wiley Blackwell Handbook of Positive Psychological Interventions, Chichester: Wiley Blackwell. (Chapter 17, pp. 310 - 326).

Stillman, T.F. \& Baumeister, R. F. (2009). Uncertainty, belongingness, and four needs for meaning. Psychological Inquiry, Vol. $20: 249$ - 251.

Tedeschi, R.G. (1999). Violence transformed: posttraumatic growth in survivors and their societies. Aggression and Violent Behavior, Vol. 4 (3): 319-341.

Tennant, R., Hiller, L., Fishwick, R., Platt, S., Joseph, S. Weich, S., Parkinso, J., Secker, J. \& Stewart-Brown, S. (2007). The Warwick-Edinburgh Mental Well-being Scale (WEMWBS): development and UK validation. Health and Quality of Life Outcomes, Vol. 5: 63 - 75. 
Tribe, R. \& Tunariu, A.D. (in press). Psychological Interventions in the context of Cultural Psychiatry. In D. Bhugra and K. Bhui (Eds). Textbook of Cultural Psychiatry. Cambridge: Cambridge University Press.

Tunariu, A.D. (2015). The iNEAR psychological intervention. A resilience curriculum programme for children and young people. Teacher and Student Guides. UEL, London, UK.

Tunariu, A.D. (2017a). Positive Psychology in my practice. Presentation and workshop at the "Adverse Childhood Experiences (ACEs): What it means for you" Public Health Network Cymru Conference, Cardiff, Wales.

Tunariu, A.D. (2017b). Coaching for resilience within an Islamic context (case study). In C. van Nieuwerburgh and R. Al-Laho. The Principles and Practice of Coaching in Islamic Culture. London: Karnac.

Tunariu, A.D., \& Tribe, R. (2015). Recognising individual resources as a social asset in tackling radicalisation. The iNEAR psycho-social intervention programme: resilient communities, existential responsibility, and social ethics. Paper presented at the Symposium on "Global Mental Health: conflict, identity and compassion" at the 4th World Congress of Cultural Psychiatry, World Association of Cultural Psychiatry, Puerto Vallarta, Mexico.

Tunariu, A.D., Boniwell, I., Ruffion, A. \& Clamy - Sebag, V. (2017). Towards sustainable prevention of youth radicalization. The Philosophical Dialogues Program - An existential positive psychology intervention for resilience, wellbeing and affirmative mindset. Manual and training materials. University of East London, UK \& UNISMED Association, France.

Ungar, M., \& Liebenberg, L. (2011). Assessing resilience across cultures using mixed methods: Construction of the Child and Youth Resilience Measure. Journal of Mixed Methods Research, Vol.5: 126 - 149.

Van den Bos, K. (2009). Making Sense of Life: The Existential Self trying to deal with personal uncertainty, Psychological Inquiry, Vol. 20 (4): 197-217.

Van den Bos, K., Poortvliet, P.M., Maas, M., Miedema, J., \& Van den Ham, E.J., (2005). An inquiry concerning the principles of cultural norms and values: the impact of uncertainty and moral salience on reactions to violations and blostering cultural worldviews. Journal of Experimental Social Psychology, Vol. 41: 91 - 113.

Wagnild, G. (2003). Resilience and successful aging: Comparison among low and high income older adults. Journal of Gerontological Nursing, Vol. 29: $42-49$.

Winnicott, D. (1958). The capacity to be alone. In D. Winnicott The maturational process and the facilitating environment. London: Hogarth.

Wong, P. T. P. (2010). What is existential positive psychology? International Journal of Existential Psychology and Psychotherapy, Vol. 3: 110. 
Table 1. iNEAR's core domains of change, with respective predicted outcomes and associated measures of evaluation.

\begin{tabular}{|c|c|c|c|}
\hline Lesson & $\begin{array}{l}\text { Four Core } \\
\text { Domains of Change }\end{array}$ & $\begin{array}{l}\text { Effectiveness: operational } \\
\text { definitions }\end{array}$ & $\begin{array}{l}\text { Key psychometric tools per each domain. } \\
\text { (Note: the evaluation used several numeric as well as text-based methods } \\
\text { (e.g., sentence completion; focused groups). }\end{array}$ \\
\hline $1 \& 2$ & $\begin{array}{l}1 \\
\text { Self-concept \& Self- } \\
\text { relatedness } \\
\text { [Positive Identity]. }\end{array}$ & $\begin{array}{l}\text { Hypothesised changes: } \\
\text { increased self-knowledge; } \\
\text { more sophisticated appraisal } \\
\text { of self-worth; greater sense of } \\
\text { self-efficacy and sense that } \\
\text { personal actions make a } \\
\text { difference. }\end{array}$ & $\begin{array}{l}\text { Environmental Mastery. A 9-item subscale; a dimension of the } \\
\text { Psychological Well-Being Scale (Ryff, 1998). Structured as a 6-point scale: } \\
\text { none of the time - all of the time. High internal consistency (Cronbach's } \\
\text { alpha alpha } \alpha=.86 \text { ) and high correlation with } 20 \text {-item parent scale (.98). }\end{array}$ \\
\hline $3 \& 4$ & $\begin{array}{l}2 \\
\text { Emotional Regulation } \\
\text { \& Relating to Others } \\
\text { [Emotional } \\
\text { intelligence; } \\
\text { relational } \\
\text { Competence. }\end{array}$ & $\begin{array}{l}\text { Hypothesised changes: } \\
\text { increased emotional } \\
\text { intelligence and emotional } \\
\text { regulation; increased empathy; } \\
\text { greater awareness and } \\
\text { appreciation of positive- } \\
\text { relatedness with others as a } \\
\text { key resource. }\end{array}$ & $\begin{array}{l}\text { Positive Relationships with Others. A 9-item subscale; a dimension the } \\
\text { Psychological Well-Being Scale (Ryff, 1998). Structured as a 6-point scale: } \\
\text { none of the time - all of the time. High internal consistency (coefficient } \\
\text { alpha } \alpha=.88 \text { ) and high correlation with } 20 \text {-item parent scale (.98). }\end{array}$ \\
\hline 5 & $\begin{array}{l}3 \\
\text { Choice \& Option } \\
\text { [Perception; } \\
\text { Ideological } \\
\text { flexibility; Issues of } \\
\text { Social justice] }\end{array}$ & $\begin{array}{l}\text { Hypothesised changes: } \\
\text { increased awareness of } \\
\text { thought-traps; increased } \\
\text { flexibility of perspective, of } \\
\text { ideas and thinking; openness } \\
\text { to diversity. }\end{array}$ & $\begin{array}{l}\text { Openness to Diversity and Challenge. Two statements selected from the } \\
\text { Openness to Diversity and Challenge Scale (ODC, Pascarella, et al., 1996) } \\
\text { structured as a 5-point scale: strongly disagree - strongly agree). These are: } \\
\text { "I enjoy having discussions with people whose ideas and values are different } \\
\text { from my own" and "I enjoy talking with people who have values different } \\
\text { from mine because it helps me understand myself and my values better." } \\
\text { The two statements collapsed together into a single scale for the purpose of } \\
\text { the analysis. }\end{array}$ \\
\hline 6 & $\begin{array}{l}4 \\
\text { Responding with } \\
\text { resilience }\end{array}$ & $\begin{array}{l}\text { Hypothesised changes: } \\
\text { enhanced tolerance of } \\
\text { (personal \& existential) } \\
\text { uncertainty; working with } \\
\text { personal strengths; expanded }\end{array}$ & $\begin{array}{l}\text { Intolerance of Uncertainty Scale (IUS - 12) (Carleton, Norton \& } \\
\text { Asmundson, 2007). A } 12 \text { items (a 5-point scale: not at all characteristic of } \\
\text { me - to entirely characteristic of me) assessing reactions to uncertainty } \\
\text { based on negative beliefs, expectations and dislike of these. The lower the } \\
\text { scores, the greater individual capacity to tolerate, to manage this state of } \\
\text { being. High internal consistency ( } \alpha=.91 \text { ). For the purpose of this paper, it } \\
\text { is also theorised that the capacity to 'stay' with the anxiety associated with }\end{array}$ \\
\hline
\end{tabular}




\begin{tabular}{|c|c|c|c|}
\hline & $\begin{array}{l}\text { [Uncertainty \& } \\
\text { Existential ethics] }\end{array}$ & $\begin{array}{l}\text { self-soothing skills; enhanced } \\
\text { malleability }\end{array}$ & $\begin{array}{l}\text { uncertainty can be considered to be an indicator of an individual's point in } \\
\text { the journey towards emotional and existential maturation. }\end{array}$ \\
\hline 7 & $\begin{array}{l}4 \\
\text { Responding with } \\
\text { resilience } \\
\text { [Uncertainty \& } \\
\text { Growth \& Wellbeing] }\end{array}$ & $\begin{array}{l}\text { Hypothesised changes: greater } \\
\text { awareness of the link between } \\
\text { values, emotions and } \\
\text { behaviors; deliberate } \\
\text { orientation towards internal } \\
\text { congruence (self-governing vs. } \\
\text { compliance to pressures). }\end{array}$ & $\begin{array}{l}\text { Subjective sense of wellbeing. The } 14 \text { items Warwick-Edinburgh Mental } \\
\text { Well-being Scale (a } 5 \text { point scale: none of the time - all of the time) which } \\
\text { is a widely used measure of subjective well-being focusing on positive } \\
\text { aspects of mental health (Tennant et al., 2007). High internal consistency: } \\
\text { Cronbach's alpha of } .89 \text { (student sample) and } .91 \text { (population sample). High } \\
\text { test retest reliability at one week follow up (.83). }\end{array}$ \\
\hline
\end{tabular}


Table 2: ANCOVA tests results by outcome variable

\section{Effect type}

$\begin{array}{lll}\text { Covariate effects } & \text { Main effects } & \text { Interaction effects }\end{array}$

\begin{tabular}{|c|c|c|c|c|c|c|c|c|c|c|c|}
\hline $\begin{array}{l}\text { Outcom } \\
\text { e } \\
\text { variable }\end{array}$ & $\begin{array}{c}\mathrm{Ag} \\
\mathrm{e}\end{array}$ & $\begin{array}{l}\text { Academi } \\
\text { c } \\
\text { Achieve } \\
\text { ment }\end{array}$ & $\begin{array}{c}\text { Time X } \\
\text { Academi } \\
\text { c } \\
\text { Achieve } \\
\text { ment }\end{array}$ & $\begin{array}{c}\mathrm{Ti} \\
\mathrm{me} \\
\mathrm{X} \\
\mathrm{Ag} \\
\mathrm{e}\end{array}$ & $\begin{array}{r}\mathrm{Ti} \\
\mathrm{me}\end{array}$ & $\begin{array}{c}\text { Interve } \\
\text { ntion }\end{array}$ & $\begin{array}{l}\text { Gen } \\
\text { der }\end{array}$ & $\begin{array}{c}\text { Condi } \\
\text { tion X } \\
\text { Gend } \\
\text { er }\end{array}$ & $\begin{array}{c}\text { Time X } \\
\text { Interve } \\
\text { ntion }\end{array}$ & $\begin{array}{l}\text { Tim } \\
\text { e X } \\
\text { Gen } \\
\text { der }\end{array}$ & $\begin{array}{c}\text { Time X } \\
\text { Gender } \\
\quad \mathrm{X} \\
\text { Interve } \\
\text { ntion }\end{array}$ \\
\hline $\begin{array}{r}\text { Wellbei } \\
n g \\
(\mathrm{WEM})^{1}\end{array}$ & $\begin{array}{c}2.6 \\
2 \\
(.1 \\
06) \\
{[.0} \\
1]\end{array}$ & $\begin{array}{c}5.75 \\
(.017) \\
{[.03]}\end{array}$ & $\begin{array}{c}1.14 \\
(.287) \\
{[<.01]}\end{array}$ & $\begin{array}{c}0.1 \\
1 \\
(.7 \\
45) \\
\\
{[<.} \\
01]\end{array}$ & $\begin{array}{c}1.6 \\
1 \\
(.1 \\
97) \\
{[<.} \\
01]\end{array}$ & $\begin{array}{c}0.53 \\
(.470) \\
{[<.01]}\end{array}$ & $\begin{array}{c}3.70 \\
(.05 \\
6) \\
{[.02} \\
]\end{array}$ & $\begin{array}{c}0.86 \\
(.354) \\
{[<.04]}\end{array}$ & $\begin{array}{c}2.15 \\
(.144) \\
{[.01]}\end{array}$ & $\begin{array}{c}0.53 \\
(.46 \\
8) \\
{[<.0} \\
1]\end{array}$ & $\begin{array}{c}2.20 \\
(.140) \\
{[.01]}\end{array}$ \\
\hline $\begin{array}{r}\text { Intolera } \\
\text { nce to } \\
\text { uncertai } \\
\text { nty }^{2}\end{array}$ & $\begin{array}{c}0.7 \\
2 \\
(.3 \\
99) \\
{[<.} \\
01]\end{array}$ & $\begin{array}{c}1.28 \\
(.260) \\
{[<.01]}\end{array}$ & $\begin{array}{c}0.23 \\
(0.63) \\
{[<.01]}\end{array}$ & $\begin{array}{c}3.3 \\
3 \\
(.0 \\
69) \\
{[.0} \\
2]\end{array}$ & $\begin{array}{c}1.1 \\
4 \\
\\
(.2 \\
86) \\
{[<.} \\
01]\end{array}$ & $\begin{array}{c}1.54 \\
(.215) \\
{[<.01]}\end{array}$ & $\begin{array}{c}2.94 \\
(.08 \\
8) \\
{[.01} \\
]\end{array}$ & $\begin{array}{c}0.80 \\
(.778) \\
{[<.01]}\end{array}$ & $\begin{array}{c}4.13 \\
(.043) \\
{[.02]}\end{array}$ & $\begin{array}{c}3.28 \\
(.07 \\
2) \\
{[.02} \\
]\end{array}$ & $\begin{array}{c}0.23 \\
(.623) \\
{[<.01]}\end{array}$ \\
\hline $\begin{array}{r}\text { Emotion } \\
\text { al } \\
\text { mastery } \\
3\end{array}$ & $\begin{array}{c}5.2 \\
3 \\
(.0 \\
23)\end{array}$ & $\begin{array}{c}1.13 \\
(.289) \\
{[<.01]}\end{array}$ & $\begin{array}{c}.233 \\
(.630) \\
{[<.01]}\end{array}$ & $\begin{array}{c}0.4 \\
9 \\
(.4 \\
87)\end{array}$ & $\begin{array}{c}0.1 \\
3 \\
(.7 \\
21)\end{array}$ & $\begin{array}{c}0.61 \\
(.436) \\
{[<.01]}\end{array}$ & $\begin{array}{c}5.24 \\
(.02 \\
3)\end{array}$ & $\begin{array}{c}0.25 \\
(.610) \\
{[<.01]}\end{array}$ & $\begin{array}{c}2.51 \\
(.114) \\
{[.01]}\end{array}$ & $\begin{array}{c}1.37 \\
(.24 \\
5)\end{array}$ & $\begin{array}{c}.185 \\
(.668) \\
{[<.01]}\end{array}$ \\
\hline
\end{tabular}




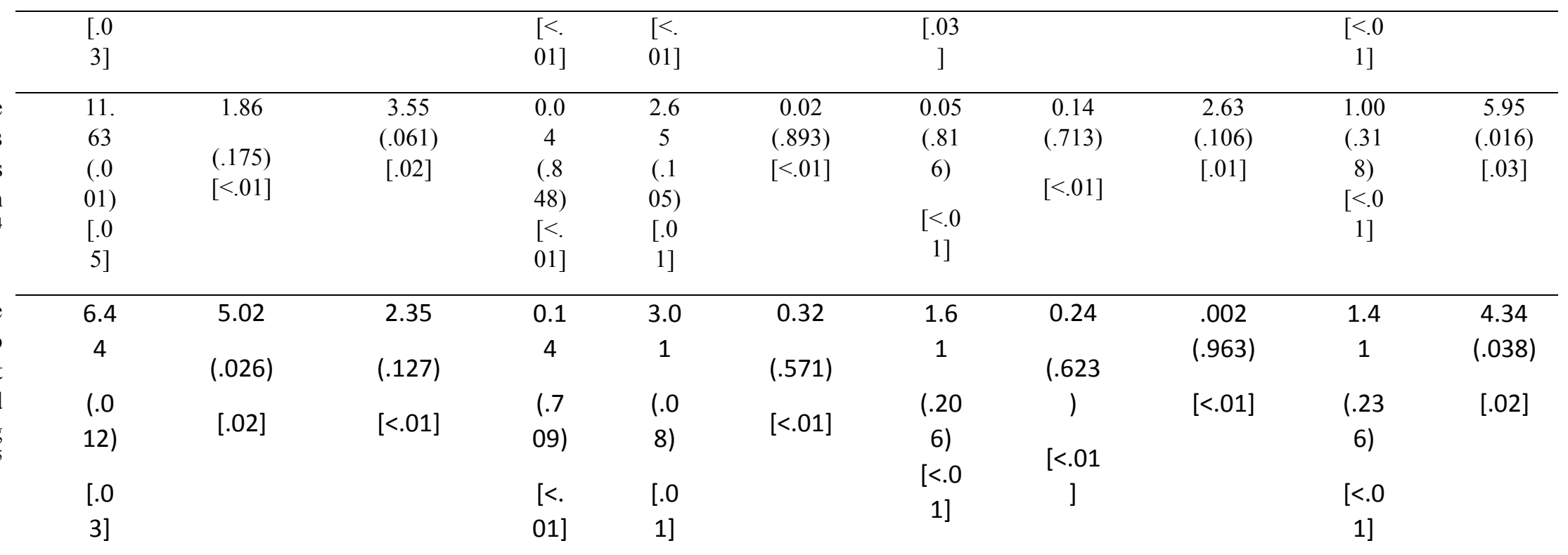

Note: Statistics for each test are reported as follows in each cell: $F,(p),\left[\right.$ eta2]. Degrees of freedom are ${ }^{1}(1,224),{ }^{2}(1,221),{ }^{3}(1,207),{ }^{4}(1,208),{ }^{5}(1,216)$. 
Table 3: Mean scores for outcome variables broken down by Time and Treatment condition (Standard Errors in parentheses).

\begin{tabular}{|c|c|c|c|c|}
\hline & & \multicolumn{3}{|c|}{ Phase } \\
\hline & & Baseline & Post & Mean difference \\
\hline \multirow[t]{2}{*}{ Wellbeing } & Intervention & $47.69(.88)$ & $50.25(.88)$ & $2.56^{*}$ \\
\hline & Control & $49.27(.88)$ & $50.33(.88)$ & 1.06 \\
\hline \multirow[t]{2}{*}{ Intolerance to uncertainty } & Intervention & $26.18(.83)$ & $25.41(.82)^{\mathrm{a}}$ & -0.77 \\
\hline & Control & $26.54(.81)$ & $27.68(.80)^{\mathrm{a}}$ & 1.14 \\
\hline \multirow[t]{2}{*}{ Emotional mastery } & Intervention & $35.67(.58)^{*}$ & $36.91(.60)$ & $1.24 *$ \\
\hline & Control & $36.89(.56)$ & $36.81(.58)$ & -0.08 \\
\hline \multirow[t]{2}{*}{ Positive relationships with others } & Intervention & $39.18(.81)$ & $40.95(.84)$ & $1.77 *$ \\
\hline & Control & $39.95(.78)$ & $39.90(.81)$ & -0.05 \\
\hline \multirow[t]{2}{*}{ Openness to diversity \& challenge } & Intervention & $3.43(.11)$ & $3.53(.10)$ & 0.10 \\
\hline & Control & $3.35(.11)$ & $3.45(.10)$ & 0.10 \\
\hline
\end{tabular}

Note: Means differences marked with $a *$ are represent statistically significant differences, $p s<.05$.In addition, in the intolerance to uncertainty condition, means marked with differ at $p<.05$ level. 
Table 4: Mean (Positive Relationships with Others \& Openness to Diversity and Challenge scores) by Gender, Treatment and Time conditions. (Standard Errors in parentheses)

\begin{tabular}{|c|c|c|c|c|c|}
\hline \multirow[t]{2}{*}{ Outcome } & \multirow[t]{2}{*}{ Gender } & \multirow[t]{2}{*}{ Treatment condition } & \multicolumn{2}{|c|}{ Phase } & \multirow[b]{2}{*}{ Mean difference } \\
\hline & & & Baseline & Post & \\
\hline \multirow[t]{8}{*}{ Positive relationships with others } & Male & Intervention & 39.51 & $40.49(1.25)$ & 0.98 \\
\hline & & & $(1.20)$ & & \\
\hline & & Control & 39.30 & $41.16(1.11)$ & 1.86 \\
\hline & & & $(1.07)$ & & \\
\hline & Female & Intervention & 38.85 & $41.42(1.12)$ & $2.57 *$ \\
\hline & & & $(1.08)$ & & \\
\hline & & Control & 40.61 & $38.65(1.19)$ & -1.96 \\
\hline & & & $(1.14)$ & & \\
\hline \multirow{8}{*}{$\begin{array}{l}\text { Openness to diversity \& } \\
\text { challenge }\end{array}$} & Male & Intervention & 7.31 & $7.05(0.29)$ & 0.26 \\
\hline & & & $(0.33)$ & & \\
\hline & & Control & 6.73 & $7.07(0.28)$ & -0.34 \\
\hline & & & $(0.31)$ & & \\
\hline & Female & Intervention & 6.36 & $7.07(0.28)$ & $0.71 *$ \\
\hline & & & $(0.31)$ & & \\
\hline & & Control & 6.66 & $6.73(0.28)$ & -0.08 \\
\hline & & & $(0.32)$ & & \\
\hline
\end{tabular}

Note: Means differences marked with $a *$ are represent statistically significant differences, $p s<.05$. 
Table 5. Towards a conceptual mapping between normal psychological variables acting as precursor components in progressing towards adopting extremist belief systems and radicalism of ideology, and normal variables that delineate the stage for personal development towards resilience, self-actualisation, inclusive social ethics and purposefull future perspectives.

\begin{tabular}{|c|c|}
\hline $\begin{array}{l}\text { Normal psychological variables as contributors } \\
\text { towards becoming susceptible to adopting an } \\
\text { extreme belief systems }\end{array}$ & Existential Positive Psychology - principles, concepts \& activities: using iNEAR as an example \\
\hline $\begin{array}{l}\text { Personal uncertainty } \\
\text { - } \quad \text { personal uncertainty in general (Doosje et al., 2013) } \\
\text { - increased uncertainty salience as a reaction to } \\
\text { events that violate worldviews (Van den Bos et al., } \\
\text { 2005) }\end{array}$ & $\begin{array}{ll}\text { - } & \text { Greater sense of self-efficacy } \\
\text { - } & \text { Increased self-knowledge } \\
\text { - } & \text { Knowing and working with personal strengths } \\
\text { - } & \text { Increase tolerance of emotional uncertainty } \\
\text { - } & \text { Increased emotional intelligence skills } \\
\text { - } & \text { Efficient inter-personal relationships } \\
\text { - } & \text { Appreciation of positive relationships with others }\end{array}$ \\
\hline $\begin{array}{l}\text { Existential uncertainty } \\
\text { - } \quad \text { as part of ordinary living } \\
\text { as result of events that increase its salience (Hogg, } \\
\text { Meeham \& Farquarson, 2010; Van den Bos, 2009) }\end{array}$ & $\begin{array}{l}\text { - Philosophical dialogues about the human existence } \\
\text { - } \quad \text { Awareness and acceptance of existential freedom and its dilemmas } \\
\text { - Skills for growth: self-compassion and self-soothing repertoires } \\
\text { - } \quad \text { Purpose and hope-engendering actions }\end{array}$ \\
\hline $\begin{array}{l}\text { Injustice } \\
\text { - } \quad \text { experiences of unfairness (Van den Bos et al., 2005) } \\
\text { - perceived injustice (Borum, 2011; Doosje et al., } \\
\text { 2013) } \\
\text { - mistrust of 'authorities' / perceived illegitimacy of } \\
\text { authority (Doosje et al., 2013) }\end{array}$ & $\begin{array}{l}\text { - } \quad \text { Working with negative emotions } \\
\text { - } \quad \text { Debate and democratic lobbying } \\
\text { - } \quad \text { Creativity and flexibility of thinking } \\
\text { - } \quad \text { Positive emotions: broadening thinking } \\
\text { - } \quad \text { Greater ideological malleability } \\
\text { - } \quad \text { Greater awareness and appreciation of positive-relatedness with others as a key personal resource }\end{array}$ \\
\hline $\begin{array}{l}\text { Perceived group threat } \\
\text { - } \quad \text { perceived group threat (Doosje et al., 2013) } \\
\text { increased worldview defense (Stillman \& } \\
\quad \text { Baumesister, 2009) }\end{array}$ & $\begin{array}{l}\text { - } \quad \text { Structure to scaffold self-concept and positive personal identity } \\
\text { - } \quad \text { Challenging and re-authoring own perceptions: alternative responses and ownership of personal choices } \\
\text { - } \quad \text { Greater empathy towards others } \\
\text { - } \quad \text { Harvesting positive emotions to (re)build bridges } \\
\text { - } \quad \text { Skills for growth: flexible (vs. rigid) personal space boundaries }\end{array}$ \\
\hline $\begin{array}{l}\text { Perceived in-group superiority } \\
\text { - } \quad \text { self-uncertainty alleviated through perceived in- } \\
\text { group superiority (Doosje et al., 2013) }\end{array}$ & $\begin{array}{l}\text { - Increased understanding of needs and purpose of emotions } \\
\text { - } \quad \text { Sophisticated self-appraisal and inclusivity of 'otherness' } \\
\text { - } \quad \text { Enhanced capacity for positive relating } \\
\text { - Skills for growth: optimised self-relatedness } \\
\text { - } \quad \text { Positive future perspectives: hope, flow, and sense of fulfilment } \\
\text { - }\end{array}$ \\
\hline
\end{tabular}

